\title{
MUTU PELAYANAN GIZI DENGAN TINGKAT KEPUASAN PASIEN
}

\author{
Iin Rachmawati*, Wiwik Afridah** \\ UNUSA, FKK, Prodi SI Keperawatan, J1. Smea 57 Surabaya \\ Email:wiwik@unusa.ac.id
}

\begin{abstract}
The quality of nutritional service is one of the indicators of the quality hospital service. Therefore, the purpose of this research was to find out the relationship between the quality of hospital nutritional service and the level of patient's satisfaction hospitalized in Teratai Room of Islamic Hospital located on Jemursari, Surabaya.The design of research was analytic cross sectional. The population of patient's hospitalized $\geq 3$ days in Teratai Room of Islamic Hospital located on Jemursari, Surabaya by 40 respondents, a sample of 36 respondents, taken using a consecutive sampling.The independent variable was the quality of hospital nutritional service, where as the dependent one was the level of patient's satisfaction. Instrument using a questionnaire sheet. Analysis of the data by the Fisher Exact Test. The result of research showed that most of the respondent $(52,2 \%)$ said the quality of nutritional hospital service is good and nearly half $(47,2 \%)$ said they were satisfied. Fisher's Exact Test statistic test value obtained $\rho$ $=0.007$ describing that there was a significant relationship between the quality of hospital nutritional service and the level of patient's satisfaction hospitalized in the hospital. The research has concluded that most of the quality nutritional of hospital service is have good and patient's have satisfaction. The nutritional official must be through, when process and prepare a dish up a food a patient
\end{abstract}

\begin{abstract}
ABSTRAK : Mutu pelayanan gizi merupakan salah satu indikator mutu pelayanan rumah sakit. Tujuan penelitian mengetahui hubungan mutu pelayanan gizi rumah sakit dengan tingkat kepuasan pasien di ruang Teratai RS Islam Jemursari Surabaya. Desain penelitian analitik cross sectional. Populasinya pasien yang rawat inap $\geq 3$ hari di ruang Teratai RS Islam Jemursari Surabaya sebesar 40 responden, sampel sebesar 36 responden, menggunakan consecutive sampling. Variabel independen adalah mutu pelayanan gizi rumah sakit dan variabel dependen adalah tingkat kepuasan pasien. Instrumen menggunakan kuesioner dan dianalisis dengan uji Fisher Exact Test. Hasil penelitian menunjukkan sebagian besar $(55,5 \%)$ menyatakan mutu pelayanan gizi rumah sakit baik dan hampir setengahnya (47,2\%) menyatakan puas. Uji statistik Fisher Exact Test didapatkan nilai $\rho=0,007$ artinya ada hubungan mutu pelayanan gizi rumah sakit dengan tingkat kepuasan pasien di ruang Teratai RS Islam Jemursari Surabaya. Simpulan adalah semakin baik mutu pelayanan gizi rumah sakit semakin tinggi tingkat kepuasan pasien. Petugas gizi hendaknya lebih teliti saat mengolah dan menyiapkan makanan yang akan disajikan ke pasien.
\end{abstract}

Kata kunci : Kualitas, pelayanan gizi, kepuasan pasien 


\section{PENDAHULUAN}

Perkembangan masyarakat yang semakin kritis, mengakibatkan mutu pelayanan di rumah sakit menjadi sorotan baik pelayanan medis maupun bentuk pelayanan lainnya. Tuntutan pasien terhadap pelayanan yang berkualitas bukan hanya dikaitkan dengan kesembuhan dari penyakit, tetapi juga menyangkut kepuasan pasien terhadap kualitas keseluruhan proses pelayanan termasuk pelayanan gizi pasien di rumah sakit. Semakin baik kualitas pelayanan gizi rumah sakit semakin tinggi tingkat kesembuhan pasien (Depkes RI, 2006). Selama ini di ruang Teratai RSI Jemursari Surabaya masih ditemukan pasien yang tidak merasa puas dengan makanan yang disajikan oleh rumah sakit, sehingga banyak pula pasien di ruangan tersebut yang tidak menghabiskan porsi makanannya. Hal itu diperkirakan karena rasa makanannya kurang enak atau hambar serta cara pengolahan dan jenis menu makanan yang disediakan kurang bervariasi sehingga pasien sering merasa bosan. Bahkan ada beberapa pasien yang tidak menyentuh makanannya sama sekali dengan alasan yang sama.

Keberhasilan suatu pelayanan gizi antara lain dikaitkan dengan daya terima pasien terhadap makanan yang disajikan, sehingga merupakan salah satu cara penentuan dari evaluasi dan dapat dipakai sebagai indikator keberhasilan pelayanan gizi. Penyajian makanan pada orang sakit lebih kompleks dibandingkan dengan penyajian makanan kepada orang yang sehat karena faktor nafsu makan dan kondisi mental pasien yang berubah akibat penyakit yang dideritanya, aktifitas fisik yang berkurang serta reaksi obat - obatan. Pembatasan ataupun larangan untuk mengkonsumsi beberapa jenis makanan tertentu yang menjadi kesukaan pasien sehubungan dengan penyakitnya, disamping waktu makan, besar porsi dan rasa makanan yang berbeda dapat mempengaruhi kepuasan pasien dalam menerima pelayanan gizi di rumah sakit. Oleh karena itu jika penerapan mutu pelayanan gizi tercapai dengan baik akan sangat berpengaruh terhadap kepuasan pasien. Pasien yang merasa puas dengan mutu pelayanan rumah sakit, akan mempergunakan atau memanfaatkan kembali fasilitas pelayanan kesehatan tersebut.

Berdasarkan permasalahan diatas perlu adanya solusi atau upaya dari pihak rumah sakit untuk meningkatkan pelayanan gizi yang ada yaitu dengan cara mengadakan penyuluhan dan konseling tentang pentingnya diet pada klien atau pasien dan keluarganya, lebih teliti dalam menetapkan siklus menu makanan supaya pasien tidak merasa bosan, bekerjasama dengan jasa boga atau cathering dalam penyelenggaraan makanan dan petugas penyaji makanan untuk lebih meningkatkan perhatian terhadap keadaan menu, tempat dan peralatan makanan sebelum disajikan ke pasien.

\section{METODE}

Desain penelitian adalah analitik dengan rancangan yang digunakan adalah cross sectional. Populasi penelitian adalah semua pasien yang rawat inap $\geq 3$ hari yang memiliki kesadaran baik dengan jenis diit TKTP di ruang Teratai RS Islam Jemursari Surabaya sebesar 40 pasien. Sampel adalah sebagian pasien yang rawat inap $\geq 3$ hari yang memiliki kesadaran baik dengan jenis diit TKTP di ruang Teratai RS Islam Jemursari Surabaya dengan jumlah sampel yang digunakan sebesar 36 pasien menggunakan teknik non probability sampling.

Dalam penelitian ini instrumen yang digunakan untuk mengukur mutu 
pelayanan gizi rumah sakit dan tingkat kepuasan pasien adalah kuesioner dengan 195. Jurnal Ilmiah Kesehatan, Vol 7, No 2, Agustus 2014., hal 193-201

pernyataan.

Data yang terkumpul diolah dan dianalisis dengan menggunakan uji statistik Chi Square dan bantuan program SPSS 17.0 For Windows dengan tingkat kemaknaan $\alpha=0,05$. Jika probabilitas < 0,05 atau $\mathrm{p}<\alpha$, maka Ho ditolak berarti ada hubungan mutu pelayanan gizi Rumah Sakit dengan tingkat kepuasan pasien. Sebaliknya, jika probabilitas > 0,05 atau $\mathrm{p}>\alpha$, maka Ho diterima yang berarti tidak ada hubungan mutu pelayanan gizi rumah sakit dengan tingkat kepuasan pasien.

\section{HASIL}

1. Data Umum

Data umum menguraikan karakteristik responden meliputi umur, jenis kelamin, tingkat pendidikan yang disajikan dalam tabel distribusi frekuensi sebagai berikut :

a. Karakteristik responden berdasarkan jenis kelamin

Tabel 5.1 Distribusi frekuensi responden berdasarkan jenis kelamin di ruang Teratai RS Islam Jemursari Surabaya Tahun 2014

\begin{tabular}{llcc}
\hline $\begin{array}{l}\mathrm{N} \\
\mathrm{O}\end{array}$ & $\begin{array}{l}\text { Jenis } \\
\text { Kelamin }\end{array}$ & Frek & Persentase (\%) \\
\hline 1 & Laki & 11 & 30,6 \\
& $\begin{array}{l}\text { Perempu } \\
\text { an }\end{array}$ & 25 & 69,4 \\
\hline & Jumlah & 36 & 100,0 \\
\hline
\end{tabular}

Sumber : Data Primer Juli 2014.

Tabel 5.1 dapat diketahui bahwa dari 36 responden sebagian besar $(69,4 \%)$ adalah pasien perempuan.

b. Karakteristik responden berdasarkan umur
Menurut Hurlock (2004) umur responden dibagi menjadi tiga an tingkat kedewasaan yaitu nuda (18-40 tahun), dewasa madya/tengah (41-60 tahun), dan dewasa lanjut (> 60 tahun).

Tabel 5.2 Distribusi frekuensi responden berdasarkan umur di ruang Teratai RS Islam Jemursari Surabaya Tahun 2014.

\begin{tabular}{llcc}
\hline No & Umur & Frek & Persentase (\%) \\
\hline 1 & $18-40$ & 22 & 61,1 \\
2 & $41-60$ & 12 & 33,3 \\
3 & $>60$ & 2 & 5,6 \\
\hline & Jumlah & 36 & 100,0 \\
\hline
\end{tabular}

Sumber : Data Primer Juli 2014. Tabel 5.2 dapat diketahui bahwa dari 36 responden sebagian besar $(61,1 \%)$ berada pada fase dewasa muda ( 18 40 tahun).

c. Karakteristik responden berdasarkan tingkat pendidikan

Menurut Notoatmodjo (2003) tingkat pendidikan responden dibagi menjadi tiga yaitu pendidikan dasar (SD, SMP/sederajat), pendidikan menengah (SMA/sederajat), dan pendidikan tinggi (Akademik/Perguruan Tinggi).

Tabel 5.3 Distribusi frekuensi responden berdasarkan tingkat pendidikan di ruang Teratai RS Islam Jemursari Surabaya Tahun 2014

\begin{tabular}{llcc}
\hline No & $\begin{array}{l}\text { Tingkat } \\
\text { Pendidikan }\end{array}$ & Frek & Persent (\%) \\
\hline 1 & Dasar & 8 & 22,2 \\
2 & Menengah & 18 & 50,0 \\
3 & Tinggi & 10 & 27,8 \\
\hline & Jumlah & 36 & 100,0 \\
\hline
\end{tabular}

Sumber : Data Primer Juli 2014.

Tabel 5.3 dapat diketahui bahwa dari 36 responden setengahnya (50\%) adalah pasien berpendidikan menengah.

2. Data Khusus 
a. Karakteristik responden berdasarkan mutu pelayanan gizi rumah sakit

Tabel 5.4 Distribusi frekuensi responden berdasarkan mutu pelayanan gizi rumah sakit di ruang Teratai RS Islam Jemursari Surabaya Tahun 2014

\begin{tabular}{llcc}
\hline No & $\begin{array}{l}\text { Mutu } \\
\text { Pelayanan } \\
\text { Gizi }\end{array}$ & $\begin{array}{l}\text { Frekue } \\
\text { nsi }\end{array}$ & Persent(\%) \\
\hline 1 & Baik & 20 & 55,5 \\
2 & Cukup & 11 & 30,6 \\
3 & Kurang & 5 & 13,9 \\
\hline & Jumlah & 36 & 100,0 \\
\hline
\end{tabular}

Sumber : Data Primer Juli 2014. 1

Tabel 5.4 dapat diketahui bahwa dari 36 responden, didapatkan sebagian besar $(55,5 \%)$ pasien menyatakan mutu pelayanan gizi rumah sakit baik.

b. Karakteristik responden berdasarkan tingkat kepuasan pasien.

Tabel 5.5 Distribusi frekuensi responden berdasarkan tingkat kepuasan pasien di ruang Teratai RS Islam Jemursari Surabaya Tahun 2014

\begin{tabular}{clcc}
\hline No & $\begin{array}{l}\text { Tingkat } \\
\text { Kepuasa } \\
\mathrm{n}\end{array}$ & $\begin{array}{l}\text { Frekue } \\
\text { nsi }\end{array}$ & Persent (\%) \\
\hline 1 & Sangat & 9 & 25,0 \\
& Puas & & \\
2 & Puas & 17 & 47,2 \\
3 & Tidak & 10 & 27,8 \\
& Puas & & \\
\hline & Jumlah & 36 & 100,0 \\
\hline
\end{tabular}

Sumber : Data Primer Juli 2014.

Tabel 5.5 dapat diketahui bahwa dari 36 responden hampir setengahnya $(47,2 \%)$ pasien menyatakan puas terhadap pelayanan gizi rumah sakit.

c. Hubungan mutu pelayanan gizi rumah sakit dengan tingkat kepuasan pasien.

Tabel 5.6 Tabulasi silang mutu pelayanan gizi rumah sakit dengan tingkat kepuasan pasien di ruang Teratai RS Islam Jemursari Surabaya Tahun 2014.

\begin{tabular}{|c|c|c|c|c|c|}
\hline \multirow[t]{2}{*}{ No } & \multirow{2}{*}{$\begin{array}{l}\text { Mutu } \\
\text { Pely } \\
\text { Gizi }\end{array}$} & \multicolumn{3}{|c|}{ Tingkat Kepuasan } & \multirow[b]{2}{*}{ Jumlah } \\
\hline & & $\begin{array}{l}\text { Sangat } \\
\text { Tidak P }\end{array}$ & $\begin{array}{l}\text { Puas } \\
\text { las }\end{array}$ & Puas & \\
\hline 1 & Baik & 7 & $\begin{array}{c}10 \\
50 \%\end{array}$ & $\begin{array}{r}3 \\
15 \%\end{array}$ & $\begin{array}{c}20 \\
100 \%\end{array}$ \\
\hline 2 & Cukup & $\begin{array}{r}35 \% \\
2 \\
18,2 \%\end{array}$ & $\begin{array}{c}7 \\
63,6 \%\end{array}$ & 2 & $\begin{array}{c}11 \\
100 \%\end{array}$ \\
\hline 3 & Kurang & $\begin{array}{r}0 \\
0 \%\end{array}$ & $\begin{array}{c}0 \\
0 \%\end{array}$ & $\begin{array}{r}5 \\
100 \%\end{array}$ & $\begin{array}{c}5 \\
100 \%\end{array}$ \\
\hline & Jumlah & $\begin{array}{c}9 \\
25 \%\end{array}$ & $\begin{array}{c}17 \\
47,2 \%\end{array}$ & $\begin{array}{r}10 \\
27,8 \%\end{array}$ & $\begin{array}{c}36 \\
100 \%\end{array}$ \\
\hline
\end{tabular}

Sumber : Data Primer Juli 2014.

Tabel 5.6 menunjukkan bahwa dari 36 responden, 20 responden menyatakan mutu pelayanan gizi rumah sakit baik setengahnya (50\%) responden puas, sedangkan dari 11 responden yang menyatakan mutu pelayanan gizi rumah sakit cukup baik sebagian besar $(63,6 \%)$ responden puas, dan dari 5 responden yang menyatakan mutu pelayanan gizi kurang baik seluruhnya (100\%) responden tidak puas.

Hasil uji korelasi statistik Chi Square didapatkan nilai $\rho=0,003$ akan tetapi tabulasi silang tidak memenuhi uji Chi Square karena ada lima sel yang tidak memenuhi syarat jadi uji yang digunakan adalah uji Fisher's Exact Test didapatkan $\rho=$ 0,007 berarti $\rho<0,05$ maka $\mathrm{H}_{\mathrm{o}}$ ditolak yang berarti ada hubungan antara mutu pelayanan gizi rumah sakit dengan tingkat kepuasan pasien di ruang Teratai RS Islam Jemursari Surabaya.

\section{PEMBAHASAN}

1. Mutu pelayanan gizi rumah sakit

Berdasarkan hasil penelitian menunjukkan bahwa pada Tabel 5.4 dari 36 responden sebagian besar $(55,5 \%)$ pasien menyatakan mutu pelayanan gizi rumah sakit baik, artinya bahwa mutu pelayanan gizi RS Islam Jemursari Surabaya sudah dirasakan baik oleh sebagian besar 
pasien. Menurut Richard (2004), pelanggan memiliki sifat yang individual dan setiap orang akan memandang sesuatu secara berbeda dari orang lain meskipun dalam situasi yang sama. Perbedaan perspektif tersebut antara lain disebabkan oleh perbedaan latar belakang, jenis kelamin, usia, dan pendidikan.

Jenis kelamin dapat mempengaruhi perspektif seseorang. Berdasarkan Tabel 5.1 diperoleh, bahwa dari 36 responden sebagian besar $(69,4 \%)$ adalah responden perempuan. Lebih banyaknya responden perempuan dibandingkan laki-laki disebabkan karena perempuan lebih kritis dalam penilaian citarasa menu makanan dibandingkan laki-laki.

Selain jenis kelamin, usia juga dapat mempengaruhi perspektif seseorang. Dalam penelitian ini pembagian usia didasarkan pada tingkat kedewasaan karena tingkat kedewasaan dapat mempengaruhi persepsi atau cara berfikir seseorang dalam menilai sesuatu. Berdasarkan Tabel 5.2 diperoleh, bahwa dari 36 responden sebagian besar $(61,1 \%)$ berada pada fase dewasa muda yaitu 18-40 tahun. Seseorang yang berusia lebih muda akan lebih kritis dan objektif dalam menilai sesuatu yang diterima dibandingkan dengan yang berusia lebih tua. Hal ini sesuai dengan pendapat Kotler (2009) yang menyatakan seseorang yang lebih tua telah berpengalaman sehingga ia mampu menyesuaikan diri dengan kondisi pelayanan yang sebenarnya, sedangkan yang berusia lebih muda biasanya mempunyai harapan yang ideal tentang pelayanan yang diberikan.

Tingkat pendidikan dapat mempengaruhi perspektif seseorang. Berdasarkan Tabel 5.3 diperoleh setengahnya (50\%) adalah responden yang memiliki tingkat pendidikan menengah. Responden yang memiliki tingkat pendidikan menengah akan lebih mudah menerima dan menghargai apa yang mereka dapatkan serta dari segi pemikiran lebih mampu untuk mengontrol keinginan. Menurut Kotler (2009), tingkat pendidikan akan berpengaruh pada nilai yang dianut, cara pikir, cara pandang dan persepsi orang tersebut. Masyarakat yang berpendidikan tinggi karena pengetahuan yang dimiliki, lebih menuntut pelayanan yang lebih baik.

Hasil rekapitulasi data mutu pelayanan gizi menunjukkan bahwa dari seluruh indikator mutu pelayanan gizi terdapat beberapa indikator yang dinilai baik oleh responden. Hal tersebut dapat dilihat dari rekapitulasi kuesioner, pernyataan no 2 menunjukkan bahwa dari 36 responden hampir seluruhnya $(80,5 \%)$ menyatakan pengulangan variasi menu makanan pernah disajikan kembali. Hal ini dikarenakan menu makanan yang disajikan disukai oleh pasien. Pernyataan no 7 menunjukkan bahwa hampir seluruhnya $(80,5 \%)$ menyatakan tempat makanan yang disajikan terlihat bersih. Pernyataan no 8 menunjukkan bahwa hampir seluruhnya $(80,5 \%)$ menyatakan tempat makanan yang disediakan sesuai dengan jenis menu makanan. Pernyataan no 10 menunjukkan bahwa hampir seluruhnya $(97,2 \%)$ menyatakan menu makanan ditempatkan pada tempat yang terpisah. Pernyataan no 11 menunjukkan bahwa hampir seluruhnya $(80,6 \%)$ menyatakan petugas pengantar makanan bersikap sopan dan ramah saat menghidangkan makanan. Pernyataan no 12 menunjukkan bahwa hampir seluruhnya $(83,4 \%)$ menyatakan petugas pengantar 
makanan berpenampilan rapi dan bersih.

Hal tersebut menunjukkan bahwa mutu pelayanan gizi sudah dirasakan baik oleh hampir seluruh responden. Mutu pelayanan gizi yang dirasakan baik oleh responden terdiri dari pengulangan variasi menu makanan yang disukai oleh pasien, kebersihan tempat makanan, penyajian menu makanan sesuai pada tempatnya serta sikap dan penampilan petugas pengantar makanan. Menurut Wijono (2000) menyatakan bahwa jika struktur atau input (sarana fisik perlengkapan dan peralatan) di suatu pelayanan kesehatan baik kemungkinan besar mutu pelayanan pun akan baik pula.

Dari seluruh indikator masih didapatkan indikator yang dinilai kurang oleh responden. Hasil rekapitulasi kuesioner pernyataan no 1 menunjukkan bahwa dari 36 responden sebagian besar $(58,4 \%)$ menyatakan menu makanan kurang bervariasi. Pernyataan no 4 menunjukkan bahwa hampir seluruhnya $(77,8 \%)$ menyatakan makanan yang disajikan tidak dalam keadaan hangat. Pernyataan no 9 menunjukkan bahwa sebagian besar $(61,1 \%)$ menyatakan menemukan benda asing seperti potongan tissue yang tercampur dalam makanan. Hal ini dikarenakan kurangnya ketelitian petugas gizi dalam proses pengolahan dan penyajian menu makanan sebelum disajikan ke pasien. Suhu makanan pasien juga perlu diperhatikan karena makanan yang masih hangat secara tidak langsung mempengaruhi nafsu makan pasien. Menurut Pohan (2007) pada hakikatnya pelayanan yang dianggap bermutu adalah pelayanan yang dapat memenuhi kebutuhan yang dirasakan dengan sabar, sopan, tanggap, perhatian, dan mampu mengurangi keluhan.
2. Tingkat kepuasan pasien Berdasarkan Tabel 5.5 menunjukkan bahwa dari 36 responden hampir setengahnya $(47,2 \%)$ pasien menyatakan puas terhadap pelayanan gizi rumah sakit. Hal ini menunjukkan bahwa mutu pelayanan gizi rumah sakit sudah dirasakan puas oleh hampir sebagian besar responden, karena pelanggan adalah prioritas utama maka kepuasan pelanggan dijamin dengan memberikan pelayanan yang melebihi harapan dan menghasilkan produk yang berkualitas tinggi. Pelanggan dipandang sebagai unsur penentu penilaian baik buruknya pelayanan yang ada di rumah sakit. Kepuasan pelanggan yang rendah akan berdampak pada jumlah kunjungan. Faktor yang dapat mempengaruhi kepuasan yaitu kualitas produk atau jasa, kualitas pelayanan, harga dan biaya (Budiastuti, 2002).

Hasil rekapitulasi kuesioner tingkat kepuasan pasien, pernyataan no 5 menunjukkan bahwa dari 36 responden hampir seluruhnya $(80,5 \%)$ menyatakan peralatan makanan yang digunakan bersih dan tertutup rapi ketika disajikan ke pasien. Pernyataan no 6 menunjukkan bahwa sebagian besar $(66,7 \%)$ menyatakan porsi menu makanan yang disajikan sesuai dengan kebutuhan. Pernyataan no 9 menunjukkan bahwa hampir seluruhnya $(77,7 \%)$ menyatakan petugas pengantar makanan bersikap ramah dan mengucapkan salam ke pasien. Pernyataan no 12 menunjukkan bahwa sebagian besar $(55,5 \%)$ menyatakan petugas gizi bersedia mendengarkan keluhan dan memberi leaflet kepada pasien. Adanya keterkaitan yang erat antara kebersihan peralatan makanan, porsi menu makanan, dan sikap petugas 
pengantar makanan sehingga dapat menimbulkan kepuasan pasien.

Sedangkan hasil rekapitulasi kuesioner pernyataan no 1 menunjukkan bahwa dari 36 responden sebagian besar $(63,9 \%)$ menyatakan cara pengolahan dan menu makanan yang disajikan kurang bervariasi. Pernyataan no 4 menunjukkan bahwa sebagian besar $(58,3 \%)$ menyatakan petugas pengantar makanan tidak menginformasikan batas jam waktu makan. Pernyataan no 7 menunjukkan bahwa sebagian besar $(72,2 \%)$ menyatakan citarasa menu makanan yang disajikan tidak sesuai dengan selera makan pasien. Pernyataan no 8 menunjukkan bahwa sebagian besar $(63,9 \%)$ menyatakan pasien baru masuk rawat inap tidak diberikan diit tepat waktu. Pernyataan no 11 menunjukkan bahwa sebagian besar $(52,8 \%)$ menyatakan petugas gizi tidak memberikan konsultasi gizi tentang diit kepada pasien. Hal ini dikarenakan apa yang didapatkan tidak sesuai dengan apa yang diharapkannya terutama dalam hal pengolahan menu makanan, informasi batas jam waktu makan, citarasa menu makanan, ketepatan waktu pemberian diit pasien baru, serta konsultasi petugas gizi kepada pasien.

Kualitas pelayanan dapat mempengaruhi kepuasan pelanggan. Menurut Tjiptono (2006) menyatakan bahwa mutu pelayanan dinilai baik dan memuaskan, apabila jasa yang diterima atau dirasakan sesuai dengan yang diharapkan, jika mutu pelayanan yang diterima melampaui harapan pelanggan maka mutu pelayanan dinilai sebagai kualitas yang ideal, sebaliknya jika kualitas pelayanan lebih rendah dari yang diharapkan maka kualitas pelayanan dinilai buruk.
3. Hubungan mutu pelayanan gizi rumah sakit dengan tingkat kepuasan pasien

Hasil uji Fisher's Exact Test didapatkan $\rho=0,007$ berarti $\rho<0,05$ sehingga $\mathrm{H}_{\mathrm{o}}$ ditolak yang artinya ada hubungan antara mutu pelayanan gizi rumah sakit dengan tingkat kepuasan pasien di ruang Teratai RS Islam Jemursari Surabaya. Berdasarkan Tabel 5.6 hubungan mutu pelayanan gizi rumah sakit dengan tingkat kepuasan pasien di ruang Teratai RS Islam Jemursari Surabaya menunjukkan bahwa mutu pelayanan gizi rumah sakit cukup baik sebagian besar $(63,6 \%)$ responden puas. Hal tersebut disebabkan karena kurangnya pemahaman pasien tentang standar mutu pelayanan gizi rumah sakit. Sehingga dengan pelayanan gizi yang ada, pasien bisa lebih mudah untuk menerimanya. Jadi dengan mutu pelayanan gizi cukup baik pasien sudah merasa puas. Sedangkan mutu pelayanan gizi rumah sakit kurang baik seluruhnya (100\%) responden tidak puas. Hal tersebut dikarenakan pelayanan gizi yang diperoleh tidak sesuai dengan yang diharapkan. Pelayanan yang tidak sesuai dengan harapan akan ditinggalkan oleh pengguna jasa pelayanan. Hal ini sesuai dengan pendapat Wijono (2000) yang menyatakan bahwa bila penampilan melebihi harapan pelanggan sangat puas dan senang, bila penampilan sebanding dengan harapan pelanggan puas, dan bila penampilan kurang dari harapan pelanggan tidak puas.

Peningkatan mutu pelayanan gizi rumah sakit harus lebih diperhatikan dan ditingkatkan supaya tercipta mutu pelayanan yang baik sehingga timbul kepuasan terhadap diri pelanggan atau responden. Keluhan responden tentang pelayanan di rumah sakit tentu perlu 
dihindari.

Kesan

yang

mengecewakan ini menyebabkan responden tidak akan menggunakan kembali pelayanan yang ada di rumah sakit karena responden merasa tidak puas dengan pelayanan yang tidak sesuai dengan tuntutan dan harapannya. Hal ini sesuai dengan pendapat Supriyanto (2010) yang menyatakan kepuasan adalah perbandingan antara apa yang diterima atau dirasakan (perceived performance) sama atau melebihi apa yang diharapkannya.

Mutu pelayanan gizi rumah sakit bisa diukur dari penyelenggaraan pelayanan yang memiliki kualitas yang baik tetapi bila dilihat dari pandangan pasien yaitu membandingkan kualitas pelayanan yang diharapkan dengan pelayanan yang diterima. Cara yang tepat untuk melakukan perbaikan tentang tanggapan pasien tersebut dengan pro aktif terhadap keluhan dan harapan pasien dengan cara melakukan survei kepuasan pelanggan, sistem keluhan dan saran. Dengan cara tersebut bisa membantu mempermudah penyedia jasa untuk memperbaiki pelayanan yang ada dan mengetahui harapan dan keinginan pelanggan terhadap penyedia jasa. Hal ini bisa membantu penyedia jasa untuk memberikan pelayanan yang bermutu baik dan pelanggan puas terhadap jasa yang disediakan, serta pelanggan dapat mempergunakan kembali jasa pelayanan yang ada di rumah sakit tersebut.

\section{SIMPULAN}

1. Pasien yang dirawat $\geq 3$ hari dengan jenis diit TKTP di ruang Teratai RS Islam Jemursari Surabaya sebagian besar menyatakan mutu pelayanan gizi rumah sakit baik.

2. Pasien yang dirawat $\geq 3$ hari dengan jenis diit TKTP di ruang
Teratai RS Islam Jemursari Surabaya hampir setengahnya menyatakan puas terhadap mutu pelayanan gizi rumah sakit.

3. Ada hubungan mutu pelayanan gizi rumah sakit dengan tingkat kepuasan pasien di ruang Teratai RS Islam Jemursari Surabaya.

\section{DAFTAR PUSTAKA}

Almatsier, S (2004). Penuntun Diit.

Jakarta, Gramedia Pustaka Utama

Amirudin, R. (2007). Pendekatan Mutu $\begin{array}{ll}\text { dan Kepuasan Pelanggan } \\ \text { Dalam Pelayanan } & \text { Kesehatan. } \\ \text { Jakarta, EGC } & \end{array}$

Aritonang, Irianton (2002).

Penyelenggaraan Makanan. Jakarta, Leutika

Bakri dan Annasari (2010). Etika dan Profesi Gizi. Yogyakarta, Graha Ilmu

Budiastuti (2002). Kepuasan Pasien Terhadap Pelayanan Rumah Sakit.

http://klinis.wordpress.com diunduh Sabtu, 05 April 2014

Bustami (2011). Penjamin Mutu Pelayanan Kesehatan dan Akseptabilitasnya. Jakarta, Erlangga

Depkes RI (2003). Pedoman Pelayanan Gizi Rumah Sakit. Jakarta, Direktorat Jenderal Bina Kesehatan Masyarakat

Depkes RI (2006). Pedoman Pelayanan Gizi Rumah Sakit. Jakarta, Direktorat Jenderal Bina Kesehatan Masyarakat

Depkes RI (2013). Pedoman Pelayanan Gizi Rumah Sakit. Jakarta, Direktorat Jenderal Bina Kesehatan Masyarakat

Erni (2012). Media Gizi Masyarakat Indonesia. http://journal.ac.id diunduh Kamis, 03 April 2014

JCHO (2004). Mutu Pelayanan Kesehatan. www.springerlink.com diunduh Sabtu, 05 April 2014 
Kotler, Philip (2005). Marketing Manajemen. Edisi Kesebelas Jilid 1 Edisi Bahasa Indonesia. Jakarta, Indeks

Kotler, Philip (2009). Manajemen Pemasaran. Jakarta, Erlangga

Muwarni (2001) Penentuan Sisa Makanan Pasien Rawat Inap Dengan Metode Taksiran Visual Comstock di RSUP Dr. Sardjito. Thesis. Yogyakarta, Universitas Gajah Mada, tidak dipublikasikan

Nuryati (2008) Hubungan Antara Mutu penyajian Penampilan dan Rasa Makanan Dengan Sisa Makanan Pada Pasien Rawat Inap Dewasa di RS Bhakti Wira Tamtama. Skripsi. Semarang, Fakultas Ilmu Kesehatan Universitas Muhammadiyah, tidak dipublikasikan

Nursalam (2008). Konsep dan Penerapan Metodelogi Penelitian Ilmu Keperawatan : Pedoman Skripsi, Tesis dan Instrumen Penelitian. Jakarta, Salemba Medika

Pohan, Imbalo S (2007). Jaminan Mutu Layanan Kesehatan : DasarDasar, Pengertian, dan Penerapan. Jakarta : EGC

Richard (2004). Konsep Kepuasan. www.Tety staff

Gunadarma.ac.id diunduh Senin, 14 juli 2014

Supariasa (2001). Penilaian Status Gizi. Jakarta, EGC

Supriyanto, S (2005). Strategi Pemasaran Jasa Pelayanan Kesehatan. Surabaya, Administrasi dan Kebijakan Kesehatan FKM UNAIR

Supriyanto, S (2010). Manajemen Mutu Administrasi dan Kebijakan Kesehatan. Surabaya, Airlangga

Tjiptono (2006). Perspektif Manajemen dan Pemasaran Kontemporer. Yogjakarta, Nuha Medika

\author{
Tjiptono (2007). Manajemen Mutu \\ Pelayanan Kesehatan. Jakarta, \\ Pustaka Sinar Harapan \\ Wijono, Djoko (2000). Manajemen Mutu \\ Pelayanan Kesehatan. Vol 2. \\ Surabaya, Airlangga University \\ Press.
}

